\title{
Scientists protest detention of Palestinian physicist
}

\section{The Israeli military arrested Imad Ahmed Barghouthi on his way to the United Arab Emirates to attend a scientific} conference, his lawyer says.

\section{Michele Catanzaro}

21 January 2015 | Updated: 23 January 2015 | Corrected: 22 January 2015

[Update: On 22 January, the Israeli military court set Barghouthi free. The physicist says he believes that the letters of support from international scientific organizations, which were presented to the judge by his lawyer, were instrumental in persuading the court to release him. "I am a scientist and I am devoted to research but I am also a firm opponent to occupation," Barghouthi told Nature upon being freed. He says that he believes he had been jailed for wearing a green hat and scarf on his Facebook profile's picture - the colours of the Hamas, a Palestinian group that some countries have classified as a terrorist organization. But Barghouthi says he is "not a member nor a supporter of Hamas".]

Several organizations of scholars have issued letters protesting the detention of a Palestinian astrophysicist in the Israeli military's Ofer prison, in the West Bank. The scientist, Imad Ahmad Barghouthi, has been detained without charges since December. An appeal to the detention will be heard on 22 January.

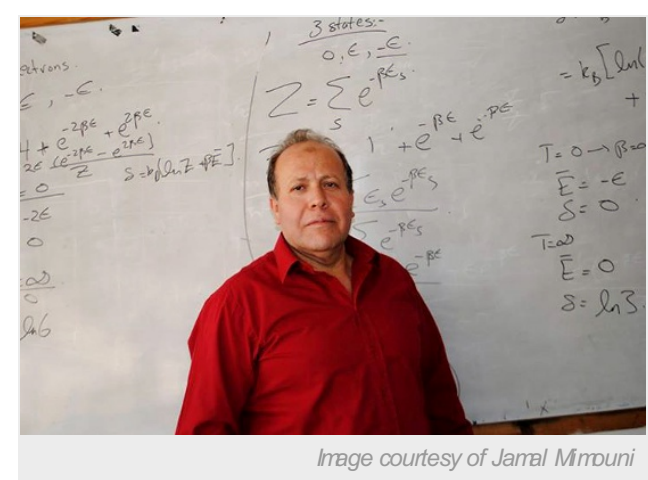

Imad Ahmad Barghouthi is a physicist at at AlQuds University in Jerusalem.

Barghouthi is a theorist of space-plasma physics at Al-Quds University, a Palestinian university in Jerusalem. He obtained his doctorate at Utah State University in Logan, and worked in Jordan and Saudi Arabia before moving to Al-Quds in 2000.

On 6 December 2014, the Israel Border Police arrested him while he was attempting to cross the border from the West Bank into Jordan, near the Jordanian town of Karama. According to multiple sources, was headed to Amman to board a flight to the United Arab Emirates, where he planned to attend a meeting of the Arab Union of Astronomy and Space Sciences in Sharjah. He was then jailed, says his lawyer, Jawad Boulos, under a three-month administrative detention order. This legal procedure allows the Israeli military in the occupied Palestinian Territories to jail a person without charges if they can claim that he or she represents a security risk.

Boulos alleges that Barghouthi was arrested because of statements he made in support of Palestinian activists during Israel's invasion of the Gaza Strip last summer. "In an interrogation after his arrest, he was asked about what he wrote on Facebook and stated on TV against the occupation," says Boulos.

The lawyer filed an appeal to the detention. In response, an Israeli military court reduced the detention time, and he is now scheduled to be released on 2 February. His detention order could still be renewed, however. To issue the verdict, a judge "relied on unrevealed documents - secret documents that I could not see", Boulos says. A second appeal is scheduled for 22 January.

On 10 January, the French Association of Academics for the Respect of International Law in Palestine and the British Committee for the Universities of Palestine sent a letter to the European Commissioner for Research, Science and Innovation. They argued that Barghouthi's detention is in violation of Israel's commitment to respect human rights under its Association Agreement with the European Union, which allows Israel to access European research funds. On 14 January, the US-based Middle East Studies Association issued an open letter to Israeli authorities, which described the jailing as a violation of academic freedom and freedom of speech. On 17 January, the US-based Committee of Concerned Scientists made the same accusations in another letter to Israeli Prime Minister Benjamin Netanyahu, which also alleged that the arrest was a violation of the freedom to travel.

"Nobody knows why he is in jail, but I don't care whether he did something wrong: it's not democratic to keep a person in jail without charges," says Ron Naaman, a chemical physicist at the Weizmann Institute of Science in Rehovot, Israel. Naaman is a member of the informal group Israeli Academicians for Peace, which he said is preparing a protest letter on Barghouthi's case. "Hundreds of people are kept under these [military] orders, but it's not very common that they are applied to scientists. It's our obligation to react," says Naaman. 
Nature contacted the Israel Border Police and the Israel Defence Forces (IDF), but there was no spokesperson available to comment at either institution. An IDF press officer, however, confirmed the main facts and said that the arrest order was not issued by the IDF, but by "another force", and that the detention was decided by a military court.

Nature I doi:10.1038/nature.2015.16770

\section{Updates \& Corrections}

Updated:The article has been updated to report the decision of the court to release Barghouthi.

Corrected:An earlier version of this article stated, incorrectly, that Barghouthi earned his PhD at the University of Utah in Salt Lake City. Instead, he went to Utah State University in Logan. 